investigate this question further. In an experiment given later, done with a lower sugar concentration than in the above, the yield of alcohol approaches the calculated amount.

Glycerol is probably not found in the cell-free fermentation, and is considered a product of cellmetabolism, a similar view to that held by Pasteur about ethyl alcohol. May not the production of glycerol and other higher alcohols be equally due to the action of soluble ferments not yet discovered?

The experiments on regeneration of yeast, which conclude part $i$., serve to show how much work remains to be done in this direction. The whole account of the general research is given in a lucid and interesting manner, and deals with many lesser matters arising out of the main thesis, each point being illustrated by tables of the actual experiments performed, and the results of the experiments are fully discussed. The author establishes himself especially firmly where other investigators have questioned some of his work.

Part ii., by Profs. Hahn and Geret, gives an account of the discovery of endotryptase by the former author, the description of the experimental work being followed by a good summary.

Part iii. is by Prof. Hahn alone, and describes the reducing properties of yeast-juice as shown by experiments performed by himself and Dr. Cathcart. Some reasons are given for the author's thinking that the reducing power is due to the same ferment, zymase, which induces alcoholic fermentation.

Part iv., by Profs. Hans Buchner and Rudolph Rapp, is on the relation of oxygen-supply to the fermenting power of living yeast-cells.

The contradictory results of previous workers are first reviewed, Pasteur's theories being considered and Chudiakow's work repeated and examined critically in detail. The latter had found that air had no effect on the fermenting power, but that it killed yeast-cells more rapidly than hydrogen, when each was drawn through a sugar solution containing a small quantity of the yeast The authors find that his results were partly due to defects in his aspiration methods, more air than hydrogen being drawn through in a given time, with consequent injury from shaking. They state also that he used a yeast of too little vitality for general conclusions. They find that neither air nor hydrogen, as such, affects the fermenting power, and that the mechanical shaking of the fluid is detrimental if it exceed a certain limit. The effects of air and hydrogen differ only in that the former induces a slight multiplication of the yeast cells, and thus leads to a rather larger production of $\mathrm{CO}_{2}$.

The authors then pass on to investigate the effect of air on cultures of yeast grown on beer-wort-gelatin with to per cent. of glucose. Here, with a free supply of air, they find one part of sugar oxidised to every five parts fermented. The yeast multiplies more rapidly under such conditions than when very little air is supplied, but in the latter case a given weight of yeast ferments more sugar.

The whole volume is full of interest and instruction, and cannot fail to give the greatest pleasure to a student of alcoholic fermentation.

Arthur Croft Hill.
AN INDIAN FLORA.

The Flora of the Presidency of Bombay. Vol. i. Ranunculaceæ to Rubiaceæ. By Theodore Cooke, C.I.E., M.A., M.A.I., LL.D., F.G.S., M.Inst.C.E.I. Pp. 645. (London: Taylor and Francis, 1901-3.) Price $27 s$.

THE labours of botanists and of a small band of foresters, in India and at Kew, have supplied us with rich stores of information as to the IndoMalayan flora. These rendered possible the issue of Sir Joseph Hooker's monumental "Flora of British India."

But British India and Malaya, including as they do countries far apart, with climates ranging in temperature from low alpine to high torrid extremes, in humidity from the perpetual aridity of the desert to the permanent moistness of the equatorial tropics, exhibit subfloras and kinds of vegetation of corresponding variety. In order to map out these separate floras of British India, including Burma, the Government of India has decided to issue a series of "regional floras." Such a series will be of great service, because the information at present available as to the floras of certain large tracts of India is lamentably deficient. This deficiency Sir George King's inauguration of a botanical survey of India is calculated to remove.

For the preparation of the first of the " regional floras"- that of Bombay Presidency-the Government of India was fortunate enough to secure the services of Dr. T. Cooke.

To write an ideal "flora " of Bombay is at present impossible. For such a work should not only enable persons to identify plants found in the Presidency, but should also give information as to the geographical distribution of the indigenous species, including their general and local distribution, their habitats, and their frequency of occurrence; it should also impart information, often unavailable to the worker in Europe, as to the habits, colours, dates of flowering, of sprouting, and of defoliation. Finally, it should give a general account of the whole flora and vegetation of the region, and map out their subdivisions within that region. The present "flora" does not contain all these desiderata, for it is not yet concluded, and much remains to be discovered in regard to the local distribution and periodicity of the Bombay plants. This, the first volume, includes the whole of the Polypetalæ, following Hooker's sequence of orders, and the natural order Rubiaceæ.

The characters exhibited by the natural orders are given very fully, so much so that an inexperienced person would find it difficult to decide upon the really salient features. This difficulty might be reduced by printing important diagnostic characters in different type. But when the work is finally complete, the author may aid the tyro by giving abbreviated diagnoses, or possibly an analytical key of the natural orders.

In describing genera and species of exotic plants the botanist working in a herbarium is often at a disadvantage. The specimens reaching him are frequently comparatively small, their colours are changed, 
and the information supplied by the collector regarding them may be meagre. But Dr. Cooke, with his ripe experience in India, is in a position of vantage. His descriptions of genera and species are clear and vivid, and at times include information on regetative characters that can be observed only on the spot. It may be suggested, however, that an even more free record of vegetative characters would greatly facilitate the identification of a plant by a person happening to meet with it in blossom but not in fruit, and would supply botanists at a distance with valuable information otherwise inaccessible. To take specific examples. The two indigenous lythraceous genera with indefinite stamens, Lagerstrœmia and Sonneratia, are distinguished from one another in the analytical key by their fruits; yet their habits and habitats are sufficiently dissimilar to be of immediate use in an analytical key, but we are not told in the present work whether or no Sonneratia apetala possesses the erect respiratory roots so characteristic of $S$. acida. Again, in the Rhizophoraceæ, the four genera of the saline swamps and littoral situations are at once separable from the inland Carallia by their habitats, apart from the seeds, which are used as the basis of distinction in the analytical key. Furthermore, species of Rhizophora emit aërial roots from their epigeous branches, and thus stand apart from other rhizophoraceous plants, and, indeed, so far as I know, from all mangrove plants except Acanthus ilicifolius. Surely the mention of these roots would greatly facilitate recognition of species of Rhizophora, yet no mention is made of them; and if, as is quite conceivable, these species are apt not to possess them in Bombay Presidency, information to this effect would be of extreme interest to botanists. Whilst discussing vegetative characters, it may be remarked that the "white spongy bodies" in the shoots of Jussiaea repens are adventitious roots, not stipules. And the generally accepted view in regard to the leaves of Rubia is that they are stipulate, but that the stipules are often leaflike in form.

Dr. Cooke's analytical keys of genera and species are, it need hardly be stated, admirable examples of the approved form, and he may be wise in adhering to the system that experience has shown to be most userul, even though it frequently assumes that a person using the "flora" possesses shoots, flowers and fruits of the specimen he desires to identify.

The attractive and clear detailed descriptions of the species are succeeded in most cases by mention of the times of flowering. In many instances there is no record as to whether a plant described is deciduous or evergreen. Records on this point, coupled with additional information as to the times of opening of floral and vegetative buds, and of the shedding of the leaves, would throw much light upon the scarcely touched subject of the periodicity of plant-life in the tropics. As this subject has, in addition, considerable practical economic significance, it is to be hoped that authors of the Indian " regional floras" will record such of these data as are known, and will thereby stimulate further observation.

On the question of geographical distribution, facts NO. I 765 , VOL. 68] are given as to the occurrence of the indigenous species in places outside the Presidency, and many details are added concerning their frequency of occurrence, localities and habitats, within the Presidency. But the author specially directs attention to the need for information on the local distribution of species. Despite of this lack of complete information, the hope may be expressed that Dr. Cooke will include in his work some account of the floristic subdivisions of the Presidency dealt with, and that the authors of other Indian "regional fioras" will do likewise. Of equal scientific interest, and probably of greater practical importance, would be an account of the distribution of types of vegetation, or plant-formations, within the area. Such an account of the distribution of types of vegetation within Bombay Presidency would be of especial botanical interest, for

"the rainfall varies... from 3 or 4 inches, or even less in the almost rainless districts of Sind, to upwards of 300 inches on the Western Gháts."

The vegetation shows corresponding diversity, varying from arid or rocky desert-tracts to moisture-laden evergreen forests. As to the practical aspect, we now recognise that vegetation reflects in its form the environment, and that plants, when their actions are interpreted aright, are more cunning analysts of external conditions, including soil and climate, than are the most accomplished chemists and meteorologists.

Brief references to the economic uses of many of the species described, and vernacular names, add value to the book before us.

In conclusion, Dr. Cooke is to be congratulated on producing a most excellent work.

Percy Groom.

\section{THE STUDY OF FERMENTATION.}

Fermentation Organisms, a Laboratory Handbook. By Alb. Klocker. Translated from the German by G. E. Allan, B.Sc., and J. H. Millar, F.I.C. Pp. $\mathrm{xx}+392$. (London: Longmans and Co., I903.) Price I2s, net.

THE importance of a systematic study of the microorganisms which play a part in the various processes of fermentation is making itself felt more and more as time goes on and new facts and phenomena are brought to light. The old empirical methods of twenty years ago have passed away before the marvellous changes first introduced by Hansen, and the culture of yeast is recognised as one of the secrets of success in the manufacture of the various kinds of beer. The study has long been carried on under the personal supervision of Hansen and his assistants, but until recently has been almost entirely conducted under some form of personal supervision. As in other cases, however, the study has outgrown so limited a method of teaching, and we have in this volume a laboratory handbook which will enable practical work in the culture of fermentation organisms to be more widely spread, and probably more successfully conducted, than has hitherto been the case. The volume is welcome on this account especially, but it has other claims also on the student, coming as it does from the 